\title{
Spatio-temporal analysis of the urban-rural gradient structure: an application in a Mediterranean mountainous landscape (Serra San Bruno, Italy)
}

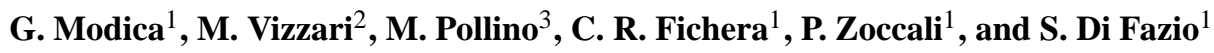 \\ ${ }^{1}$ Mediterranea University of Reggio Calabria, Department of Agroforestry and Environmental Sciences and Technologies \\ (DiSTAfA), loc. Feo di Vito c/o Facoltà di Agraria, 89122 Reggio Calabria, Italy \\ ${ }^{2}$ Department of Man and Territory, University of Perugia, Borgo XX Giugno 74, 06121 Perugia, Italy \\ ${ }^{3}$ ENEA - National Agency for New Technologies, Energy and Sustainable Economic Development, "Earth Observations and \\ Analyses" Lab (UTMEA-TER), Casaccia Research Centre - Via Anguillarese 301, 00123 Rome, Italy
}

Correspondence to: G. Modica (giuseppe.modica@unirc.it)

Received: 2 August 2012 - Published in Earth Syst. Dynam. Discuss.: 20 August 2012

Revised: 20 November 2012 - Accepted: 25 November 2012 - Published: 19 December 2012

\begin{abstract}
The most recent and significant transformations of European landscapes have occurred as a consequence of a series of diffused, varied and often connected phenomena: urban growth and sprawl, agricultural intensification in the most suitable areas and agricultural abandonment in marginal areas. These phenomena can affect dramatically ecosystems' structure and functioning, since certain modifications cause landscape fragmentation while others tend to increase homogeneity. Thus, a thorough comprehension of the evolution trends of landscapes, in particular those linked to urban-rural relations, is crucial for a sustainable landscape planning.

In this framework, the main objectives of the present paper are: (a) to investigate Land Use/Land Cover (LULC) transformations and dynamics that occurred over the period 1955-2006 in the municipality of Serra San Bruno (Calabria, Italy), an area particularly representative of the Mediterranean mountainous landscape; (b) to compare the settlement growth with the urban planning tools in charge in the study area; (c) to examine the relationship between urbanrural gradient, landscape metrics, demographic and physical variables; (d) to investigate the evolution of urban-rural gradient composition and configuration along significant axes of landscape changes.

Data with a high level of detail (minimum mapping unit 0.2 ha) were obtained through the digitisation of historical aerial photographs and digital orthophotos identifying LULC
\end{abstract}

classes according to the Corine Land Cover legend. The investigated period was divided into four significant time intervals, which were specifically analysed to detect LULC changes.

Differently from previous studies, in the present research the spatio-temporal analysis of urban-rural gradient was performed through three subsequent steps: (1) kernel density analysis of settlements; (2) analysis of landscape structure by means of metrics calculated using a moving window method; (3) analysis of composition and configuration of the urbanrural gradient within three landscape profiles located along significant axes of LULC change.

The use of thematic overlays and transition matrices enabled a precise identification of the LULC changes that had taken place over the examined period. As a result, a detailed description and mapping of the landscape dynamics were obtained. Furthermore, landscape profiling technique, using continuous data, allowed an innovative and valuable approach for analysing and interpreting urban-rural gradient structure over space and time.

\section{Introduction}

Over the last decades, the progressive world population growth has implied an increasing exploitation of resources, with a growing demand for residential space and 
a corresponding increase in industrial activities and agricultural intensity. The consequent transformations of urbanrural systems are one of the most important types of Land Use/Land Cover (LULC) changes, since they are widespread all over the world and often determine negative effects on ecosystem functionality. Although most of the actions leading to LULC changes have a local origin, nevertheless their speed, extension and intensity bring about important global implications, in particular in carbon (Foley et al., 2005) and water cycles (Turner and Rusher, 1988). Moreover, LULC changes can dramatically affect the structure and functioning of ecosystems (Defries et al., 2004; Vitousek, 1997), since certain modifications cause landscape fragmentation while others tend to increase homogeneity (Forman, 1995; Farina, 1998). Their analysis is one of the main research topics of ecology (Braimoh, 2006) and landscape ecology (Wu and Hobbs, 2002). Therefore, the evaluation of LULC present status and trends of change can provide crucial ecological information for science-oriented resource management and policy making, in relation to a wide range of human activities (Cihlar, 2000).

Urbanisation is a complex diffusion process that is dramatically spreading and variously affecting rural landscape at different spatial scales. The urbanisation process entails the transformation of landscapes, characterised by rural lifestyles, into urban ones and determines functional and structural changes, thus creating new landscape patterns (Antrop, 2000). It can give rise to the most dramatic form of irreversible land modification (Luck and Wu, 2002) which poses threats on biodiversity and landscape integrity.

Urban sprawl is an inherently dynamic spatial phenomenon defined as a specific form of urban development with low density, dispersed spatial pattern and autodependent as well as environmentally and socially impacting characteristics (Hasse and Lathrop, 2003), which can be considered as one of the main challenges in spatial planning in the 21st century (Poelmans and Van Rompaey, 2009). The term "sprawl" is often used to describe the awareness of an unsuitable development, of a disordered growth of urban areas (Sudhira et al., 2004). Taking into account its efficiency in terms of hectares of new development in relation to the number of people supported, sprawl can be considered as an "inefficient new urban growth" (Hasse and Lathrop, 2003). Thus, urban sprawl is the consequence of many individual decisions and some of its causes are population growth, economic issues and proximity to resources and basic facilities (Hoffhine Wilson et al., 2003).

Especially in the Mediterranean area, the urbanisation process is still ongoing with significant effects in landscape fragmentation and in loss of ecosystem services (EEA, 2011). Historically, urban development and agriculture have acted as counterposed activities in competition for the use of land: the expansion of cities has typically taken place on former agricultural lands (Hidding et al., 2000; Perella et al., 2010; Perchinunno et al., 2012). Just to mention a few data, between 1990 and 2000, the amount of land consumed by urban areas and associated infrastructure throughout Europe was about $800 \mathrm{~km}^{2} \mathrm{yr}^{-1}$ (EEA, 2006b). In Italy, in particular, an increase in urban pressure on the countryside can still be observed, owing to land renting and displacement of certain typical urban functions outside the cities (Murgante and Danese, 2011). This trend is a reversal of the demographic and territorial dynamics occurred during the period immediately following the Second World War and has resulted in the progressive urbanisation of rural areas; in a general increase in the number of inhabitants in the peri-urban belts; and in a decrease in resident population in towns (Alberti et al., 1994).

The Mediterranean area is one of the most significantly altered hotspots on Earth (Myers et al., 2000). Here, the widespread agricultural lands, evergreen woodlands and maquis shrublands are the result of anthropogenic disturbances occurred over centuries or even millennia (Blondel, 2006). The most recent and significant LULC changes have occurred as a consequence of a series of diffused, varied and often connected phenomena: urban sprawl; agricultural intensification in the most suitable areas and agricultural abandonment in marginal areas; more frequent and more intense summer forest fires; and rapid expansion of tourism activities and infrastructures, mainly along the coasts (Antrop, 2004; EEA, 2006b, 2011; Neri et al., 2010).

Owing to these continuous anthropic pressures and according to the different physical and climate conditions, further research is needed to monitor and analyse, in quantitative and qualitative terms, ongoing LULC changes (EEA, 2006b, 2011; Fusco Girard and De Toro, 2007; Fichera et al., 2011) and trends of urban-rural gradients. Data on urbanrural transformations are a valuable source of information in understanding the methods and the effects of urban landscape changes and trends. As a consequence, they can influence the formulation of guidelines and policies to address future growth as well as to put into practice urban greenspace protection.

The gradient approach in landscape ecological analysis allows for a more realistic representation of landscape heterogeneity by not presupposing schematisations and discretisations of the natural and anthropic environment (McGarigal and Chusman, 2005). Urbanisation can be considered as a particular environmental gradient that produces modifications on the structures and functions of the ecological system (McDonnell and Hahs, 2008). Thus, also the traditional urban-rural dichotomy can be thought as a landscape gradient, whose representation mutates depending on the natural and anthropic variables taken into account and to the spatiotemporal scale adopted for the analysis.

The urban-rural gradient paradigm is commonly used to investigate how urbanisation is changing the ecological patterns and related processes across the landscape (McDonnell and Pickett, 1990; Luck and Wu, 2002; Hahs and McDonnell, 


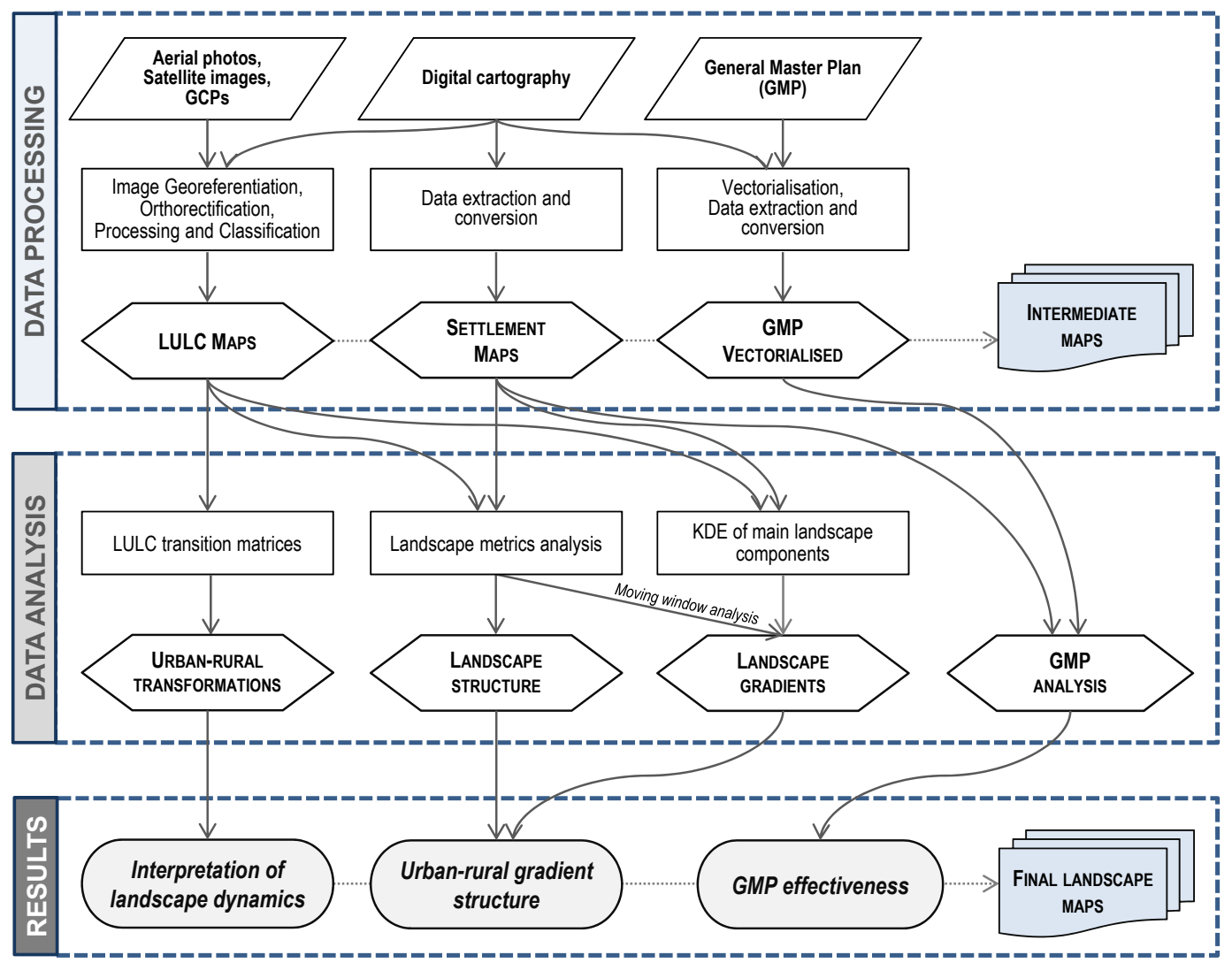

Fig. 1. Flow-chart showing the main methodological phases of the research framework.

2006; McDonnell and Hahs, 2008; Yang et al., 2010; Vizzari, 2011a).

One effective method for representing and analysing the urban-rural gradient and the urban sprawl is using Kernel Density Estimation (KDE) techniques applied on locations of buildings (Torrens and Alberti, 2000; Vizzari, 2011a). Density analysis takes measured quantities associated with point data and spreads them across the landscape to produce a continuous surface. Unlike simple density estimation, KDE produces smoother surfaces that are more representative of landscape gradients (Vizzari, 2011b). In KDE, a moving window is superimposed over a grid of locations and the density of events is estimated at each location using a distanceweighted function, with the degree of smoothing controlled by the kernel bandwidth (Gatrell et al., 1996). Since the first study on KDE proposed by Fix and Hodges (Silverman and Jones, 1989), many improvements of this smoothing technique have been developed by several authors, particularly within spatial analysis applications (see Danese et al., 2008 and references therein).

With the aim to explore the relationships between ecosystem processes and services and landscape patterns, a valuable source of information can be obtained from using landscape metrics. According to Botequilha Leitão et al. (2006), landscape is the optimal scale for sustainable land planning, considering that landscapes are usually large enough and intrinsically consistent with the scale of human perception, decision-making and physical management (Forman, 1995; Botequilha Leitão and Ahern, 2002). Landscape metrics are useful tools in mapping and quantifying spatial LULC characteristics and temporal variation (Cushman et al., 2008) as well as in understanding the process of urbanisation and its ecological effect at landscape level (Sudhira et al., 2004; Peng et al., 2010). Plenty of metrics can be efficiently calculated using specific software packages, such as FRAGSTATS (McGarigal et al., 2012), and, despite all their conceptual flaws, risks of improper use and well-known limitations (Cushman et al., 2008; $\mathrm{Li}$ and $\mathrm{Wu}, 2004$ ), they continue to be widely used in quantitative landscape ecology studies aimed at the analysis of landscape structure. Landscape metrics find a very effective application in the analysis of urban to rural gradient composition and configuration (e.g. Luck and $\mathrm{Wu}$, 2002; Hahs and McDonnell, 2006; Weng, 2007; Yang et al., 2010).

According to the research framework (Fig. 1), the objectives of this study can be summarised as follows: (a) to investigate LULC transformations, occurred in a fifty-year period in a Mediterranean forestry landscape, by means of different spatial techniques; (b) to compare the settlement growth with the urban planning tools in force in the study area; (c) to 


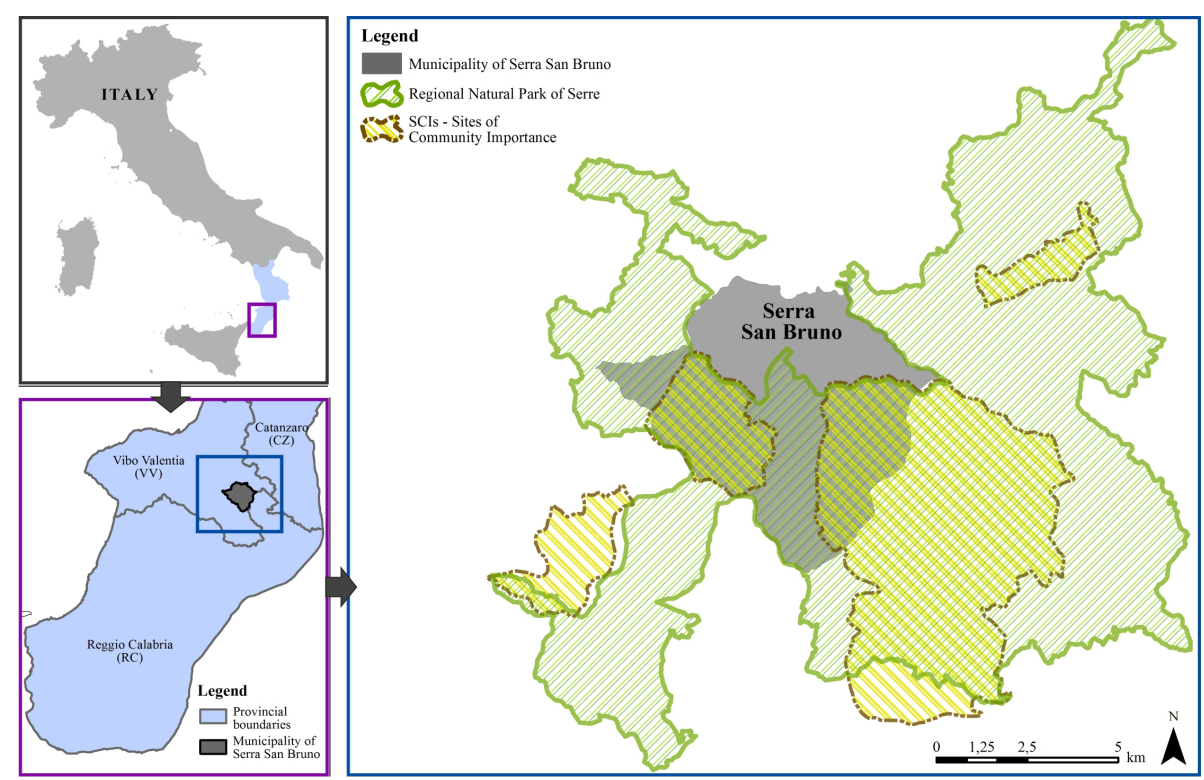

Fig. 2. Map showing the geographical location of the study area. In the blue box, the boundaries of protected areas falling in the territory of Serra San Bruno municipality are mapped.

examine the relationship between urban-rural gradient, landscape metrics and demographic and physical variables; (d) to investigate the evolution of urban-rural gradient composition and configuration along significant axes of landscape changes.

Unlike previous studies (e.g. Luck and $\mathrm{Wu}, 2002$; Hahs and McDonnell, 2006), in this research, the spatio-temporal analysis of urban-rural gradient was performed through three steps: (1) kernel density analysis of settlements; (2) analysis of landscape structure by means of metrics calculated using a moving window method; (3) analysis of the gradient composition and configuration within three landscape profiles located along significant axes of LULC change.

\section{Materials and methods}

\subsection{Study area}

The research was carried out in the territory of the municipality of Serra San Bruno (Fig. 2), located in Serre Vibonesi, a mountainous area of Calabria (a region of Southern Italy) presenting many heritage resources of great natural, historic and architectural interest.

The municipality has an area of circa 4000 ha, a residential density of 174.5 inhab. $\mathrm{km}^{-2}$ and is situated at an average altitude of $980 \mathrm{~m}$ a.s.l. Centuries-old woods, characterised by the prevalence of chestnut (Castanea sativa Miller), beech (Fagus sylvatica L.) and silver fir (Abies alba Miller subsp. apennina Brullo, Scelsi and Spampinato) populations, highlight the intrinsic suitability of this land for forestry production. Starting from the 1950s, reforestation has been practised by planting first conifers, such as the European black pine (Pinus laricio Poiret) and fir-douglas (Pseudotsuga menziesii (Mirb.) Franco), and then broadleaved trees, such as chestnut. According to Quezel and Medail (2003), EEA (2006a), Blasi et al. (2010) and Mercurio (2010), the landscape analysed can be classified as Mediterranean.

For centuries, the forests were owned by the Charterhouse of Serra San Bruno, which was founded by St. Bruno of Cologne in the 11th century. They were managed efficiently and sensitively according to the methods of the Carthusian monks. Count Roger II gave St. Bruno of Cologne the territories of Serre Vibonesi plateau to build his hermitage, the Charterhouse of Santo Stefano del Bosco, second Carthusian monastery in Europe after the one in Grenoble (France). The high environmental value of this area motivated the institution of two National Natural Reserves (now SCIs - Sites of Community Importance - of the Natura 2000 network, the centrepiece of the EU's nature and biodiversity policy) and of the Regional Natural Park of Serre in 2004. The local industrial archaeology heritage is also very significant. It is related to the utilisation of water and wood as energy sources and dates back to the time of the Bourbon rule in Calabria (XVIII-XIX centuries). Also worth mentioning is that in the same area there are many historic monastic complexes, some of which are still inhabited by the original religious orders, either Catholic or Greek Orthodox.

Over time, like the many mountainous areas of the Mediterranean basin, Serra San Bruno district has developed an economy that strongly depends on local natural resources. After the Second World War, it suffered progressive 
depopulation and many traditional economic activities, such as charcoal production, became weak and went through periods of crisis. Recently, the development of forms of tourism, based on the valorisation of the rich cultural and natural resources, has been of some help in sustaining the local economy. Tourists search for high landscape quality, which should be improved through sensitive landscape planning based on accurate monitoring of the dynamics characterising land use (Selicato et al., 2012). This is also needed for the maintenance of the environmental balance of these areas, which are particularly fragile since they are exposed to relevant hydrogeologic risk (the last catastrophic flood occurred in 1935, causing death and destruction).

\subsection{Data processing}

For the aims of this research, observation covered a period of intense and radical transformation of the Italian economic, cultural and territorial assets, ranging from the end of Second World War to present years. The first step towards the detection of LULC changes was the acquisition of all the relevant LULC maps referred to the period under investigation.

LULC changes were analysed using aerial photographs from the Italian Military Geography Institute (IGMI), for years 1955 and 1983, and digital georeferenced orthophotos from the National Geoportal (NG) of the Italian Ministry of the Environment, for years 1994 and 2006. All the aerial photographs were georeferenced by using 20-30 Ground Control Points (GCP) and orthorectified by using a Digital Elevation Model (DEM) with $10 \mathrm{~m} \times 10 \mathrm{~m}$ of spatial resolution. Four datasets with a spatial resolution of $1.37 \mathrm{~m}$ and an RMSE (Root Mean Square Error) of less than $6.5 \mathrm{~m}$ were produced. A set of 1998 orthophotos, a 1:10000 numerical topographic map and the DEM were used as reference material (for further details see Di Fazio et al., 2011).

In order to produce settlement-strata to perform the urban gradient analysis for the period under investigation, the buildings in the study area were digitised according to all the time intervals defined. In addition, a Worldview-2 scene for year 2011 was processed (Updike and Comp, 2010) in view of extracting the settlement stratum. To this end, an RGB colour orthophoto was produced from the original multispectral image that had been georeferenced and orthorectified, using $30 \mathrm{GCP}$ and the available DEM, and then pan-sharpened. A Subtractive Resolution Merge technique was used for the purpose.

\subsection{Analysis of the landscape mosaic evolution}

\subsubsection{LULC mapping changes}

LULC maps are commonly produced either by aerial visual interpretation or by classification of remotely sensed images. Definitely, photo-interpretation requires skilled analysts, is a time-consuming technique and is subjective, considering

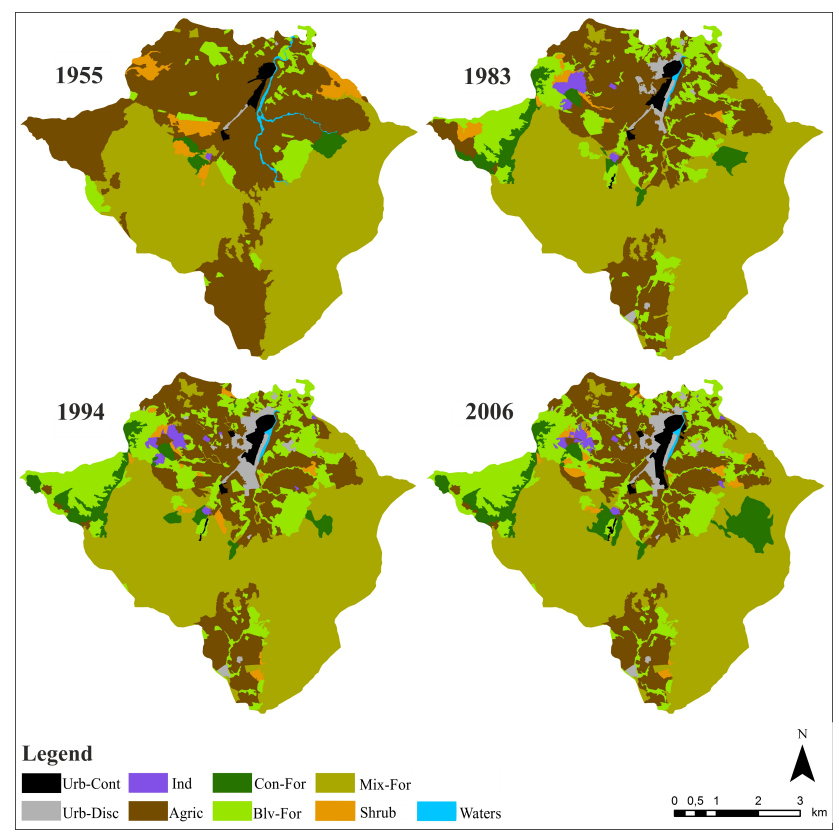

Fig. 3. LULC maps of the study area for all years under investigation and graphical representation according to the LULC class types composition.

the high degree of operator control. Nevertheless, it is still widely used and considered as a useful source of information in studies focussing on landscape pattern analysis (Zhou et al., 2009) and landscape change (Ode et al., 2010), owing to the scarcity, if not lack, of historic satellite imagery related to the years before the 1970s. In this research, LULC mapping was conducted by visual photointerpretation, thanks to the availability of aerial photographs referring to the period investigated and characterised by good frequency and high spatial resolution.

Photointerpretation was conducted by the same operator for all the years investigated (1955, 1983, 1994 and 2006) at a fixed scale of $1: 1000-1: 1500$ (minimum mapping unit $0.2 \mathrm{ha}$ ). The four LULC maps produced and their landscape composition according to the 9 LULC classes (Table 1) are shown in Figs. 3 and 4, respectively. The basic characteristics of an aerial photo used for visual interpretation are: shape, size, pattern, tone or hue, texture, shadows, geographic or topographic site and associations between features (Lillesand et al., 2003; Gomarasca, 2009). In order to reduce geometrical discordances, which could be interpreted as LULC changes, the other LULC maps were produced by updating the 2006 map and using it as reference. In order to assess the thematic accuracy of this map, a stratified random sampling was used to carry out direct surveys in 100 sampling points, distributed among LULC classes according to their surface share in landscape mosaic. The overall classification accuracy was $95.85 \%$ with a Kappa coefficient of 0.94 . The reference legend was implemented starting from the CORINE 
Table 1. Correspondence between CORINE legend nomenclature and LULC classes used for detecting LULC changes. In brackets, the symbols utilised in the text and in following figures.

\begin{tabular}{|c|c|c|}
\hline \multicolumn{2}{|c|}{ CORINE land cover legend } & LULC classes used for data analysis \\
\hline \multirow{3}{*}{ 1. Artificial surfaces } & 1.1.1 Continuous urban fabric & Continuous urban fabric (Urb-Cont) \\
\hline & $\begin{array}{l}\text { 1.1.2 Discontinuous urban fabric } \\
\text { 1.4.1 Green urban areas }\end{array}$ & $\begin{array}{l}\text { Discontinuous urban fabric (Urb- } \\
\text { Disc) }\end{array}$ \\
\hline & $\begin{array}{l}\text { 1.2.1 Industrial or commercial units } \\
\text { 1.2.2 Road and rail networks and } \\
\text { associated land } \\
\text { 1.3.1 Mineral extraction sites }\end{array}$ & $\begin{array}{l}\text { Industrial, commercial and transport } \\
\text { units (Ind) }\end{array}$ \\
\hline 2. Agricultural areas & $\begin{array}{l}\text { 2.1.1 Non-irrigated arable land } \\
\text { 2.3.1 Pastures } \\
\text { 2.4.1 Annual crops associated with } \\
\text { permanent crops } \\
\text { 2.4.2 Complex cultivation patterns } \\
\text { 2.4.3 Land principally occupied by } \\
\text { agriculture, with significant areas } \\
\text { of natural vegetation } \\
\text { 2.4.4 Agro-forestry areas }\end{array}$ & Agricultural areas (Agric) \\
\hline 3. Forests and semi-natural areas & $\begin{array}{l}\text { 3.1.1 Broad-leaved forest } \\
\text { 3.1.2 Coniferous forest } \\
\text { 3.1.3 Mixed forest } \\
\text { 3.2.4 Transitional woodland shrub } \\
\text { 3.3. Open spaces with little or no } \\
\quad \text { vegetation }\end{array}$ & $\begin{array}{l}\text { Broad-leaved forest (Blv-For) } \\
\text { Coniferous forest (Con-For) } \\
\text { Mixed forest (Mix-For) } \\
\text { Shrub and/or herbaceous } \\
\text { Vegetation associations (Shrub) }\end{array}$ \\
\hline 5. Water bodies & 5.1 Inland water & Waters bodies (Waters) \\
\hline
\end{tabular}

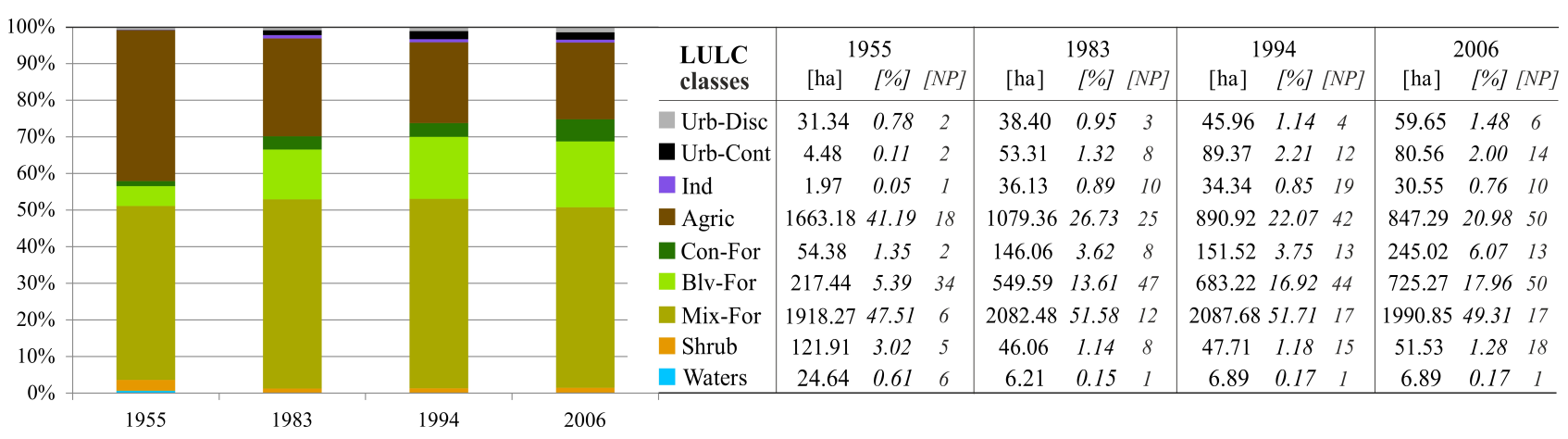

Fig. 4. Landscape composition of the study area in the four time intervals investigated, based on the 9 LULC class types. Data in [ha] and in [\%]. In addition, for each LULC class the NP (Number of Patches) is shown.

legend. The original 44 LULC classes at level III detail were aggregated in 9 classes (Table 1) so as to interpret changes as change types (Di Fazio et al., 2011).

The spatial comparison of LULC vector maps was performed for the years 1955, 1983, 1994 and 2006 by means of a post-classification comparison technique that could provide a complete matrix of change directions (Lu et al., 2004). It is a type of change detection obtained through a crosstabulation analysis which enables to highlight the changes occurred in time both in qualitative terms, by showing them directly on the map, and in quantitative terms, by allowing to calculate the total areal extent of land use change occurred at different times. Relative and absolute changes for each of the 9 LULC types were calculated from 9x9 transition matrices (or cross-tabulation matrices). The transition matrices were built for the time interval $t_{1}$ to $t_{2}$, wherein rows display the categories of time 1 and columns display the categories of time 2. While row vectors show the evolution of a land use type in the period $t_{1}-t_{2}$, column vectors show the land use type at time $t_{1}$, from which another land use type was 


\begin{tabular}{|l|c|c|c|c|c|c|c|c|c|c|}
\hline 1955 & Urb-Cont & Urb-Disc & Ind & Agric & Con-For & Blv-For & Mix-For & Shrub & Waters & Sum 1955 \\
\hline Urb-Cont & $\mathbf{3 0 . 9 8}$ & - & - & - & - & - & - & - & 0.36 & 31.34 \\
\hline Urb-Disc & - & $\mathbf{4 . 4 8}$ & - & - & - & - & - & - & - & 4.48 \\
\hline Ind & - & - & $\mathbf{1 . 9 7}$ & - & - & - & - & - & - & 1.97 \\
\hline Agric & 24.68 & 72.21 & 27.39 & $\mathbf{7 8 9 . 4 3}$ & 87.51 & 484.82 & 133.14 & 41.07 & 2.92 & 1663.18 \\
\hline Con-For & - & - & - & - & $\mathbf{1 2 . 8 6}$ & 0.36 & 39.90 & 1.20 & - & 54.38 \\
\hline Blv-For & - & 0.74 & - & 29.28 & 1.02 & $\mathbf{1 6 0 . 7 8}$ & 25.29 & 0.33 & - & 217.44 \\
\hline Mix-For & 0.27 & - & 0.75 & 8.82 & 138.18 & 18.10 & $\mathbf{1 7 4 9 . 2 1}$ & 2.93 & - & 1918.27 \\
\hline Shrub & 2.76 & 0.28 & - & 14.72 & 5.48 & 50.99 & 42.44 & $\mathbf{5 . 2 5}$ & - & 121.91 \\
\hline Waters & 1.07 & 2.76 & 0.25 & 4.98 & - & 10.41 & 0.78 & 0.76 & $\mathbf{3 . 6 1}$ & 24.64 \\
\hline Sum 2006 & 59.76 & 80.47 & 30.41 & 847.24 & 245.05 & 725.46 & 1990.77 & 51.55 & 6.89 & $\mathbf{4 0 3 7 . 6 0}$ \\
\hline
\end{tabular}

Fig. 5. Transition matrix for the Time period 1955-2006.

generated at time $t_{2}$. The data of the main diagonal, shown in bold, indicate the area of LULC persistence. In this paper, changes detected in the period 1955-2006 are reported (Fig. 5). For further information about the results of the intermediate time interval analysis (1955-1983, 1983-1994 and 1994-2006), please refer to Di Fazio et al. (2011).

\subsubsection{Landscape metrics analysis at class and landscape levels}

With the aim to better understand and describe the expanding footprints of residential and urban areas, the landscape composition and configuration of the study region was investigated by using landscape metrics. When applying spatial metrics, the spatial unit used is called patch, defined as a relatively homogeneous area that differs from its surroundings (Forman, 1995). The basis of the spatial metric calculation is a thematic map (either in vector or raster format) representing a landscape composed of spatial patches categorised in different patch classes. Landscape metrics can be defined as quantitative and aggregate measurements based on a categorical, patch-based representation of a landscape showing spatial heterogeneity at a specific scale and resolution (Herold et al., 2003, 2005) and represent one of the key factors in landscape ecological research (Uuemaa et al., 2009) and in landscape planning. According to several authors (e.g. Gustafson, 1998; Herold et al., 2003, 2005; Seto and Fragkias, 2005; Aguilera et al., 2011), the term spatial metrics relates to the characterisation of urban forms as such, while the term landscape metrics explicitly links to ecological functions. A major value of landscape metrics lies in their usefulness for comparing alternative landscape configurations, for example in evaluating the same landscape at different time periods (Gustafson, 1998).

For the purpose of this research, and according to Cushman et al. (2008), a set of limited-number landscape metrics with a valuable meaning in analysing landscape composition and configuration was selected, both at class and landscape level and for all the time intervals defined (Fig. 6 gives a short explanation for each of them). The land-use datasets (1955, 1983, 1994 and 2006) were first converted into grid format (pixel size $10 \mathrm{~m} \times 10 \mathrm{~m}$ ) in order to perform synoptic metric analyses and further analyses using the FRAGSTATS package v. 4.0 (McGarigal et al., 2012).

\subsection{Analysis of urban planning tools}

This subsequent step of the research activities was aimed to study the current urban planning tools of Serra San Bruno from their implementation until today, and to assess their stages of development. The General Master Plan (GMP) was adopted as a municipal planning tool in 1997 and is now being updated so as to help direct new urbanisation processes towards areas that are not intended for agricultural and forest use. The analyses carried out were also aimed to analyse LULC maps focussing on built-up areas, in order to evaluate their importance and role in shaping the character of the town. The processing of the above-mentioned thematic maps was performed to examine urban planning effectiveness and to provide a base to suggest recommendations for future improvements and support management tasks.

In this framework, GIS tools were used by exploiting their capability to support spatial analysis and give suggestions to planners and policy makers. One of the major benefits of this approach is that highly visual and interactive modelling and analysis can be performed. The existing raster map, which represents the GMP of Serra San Bruno, was transformed into vector format by means of semiautomatic editing. The new layer produced represents the zoning of the town according to the indication of the GMP and includes 16 different land use categories (Inner city, Completion, Expansion, Public area, Green areas, etc.) as shown in Fig. 7.

The land uses in the study area include all the categories usually found in plans conceived for typical small towns 


\begin{tabular}{|c|c|c|c|c|c|c|c|}
\hline \multirow[b]{2}{*}{ Landscape metrics } & \multirow[b]{2}{*}{ Range } & \multirow[b]{2}{*}{ Units } & \multirow[b]{2}{*}{ Description } & \multicolumn{4}{|c|}{ Years } \\
\hline & & & & 1955 & 1983 & 1994 & 2006 \\
\hline Number of Patches (NP) & $\begin{array}{l}\geq 1 \text {, without } \\
\quad \text { limit }\end{array}$ & None & Equals the number of patches in the landscape. & 76 & 122 & 167 & 179 \\
\hline Patch Density (PD) & $\begin{array}{c}\quad \geq 0 \\
\text { constrained } \\
\text { by cell size }\end{array}$ & $\begin{array}{l}\text { Number per } \\
100 \text { hectares }\end{array}$ & $\begin{array}{l}\text { Equals the number of patches of the corresponding patch type divided by } \\
\text { total landscape area }\left(\mathrm{m}^{2}\right) \text {. }\end{array}$ & 1.88 & 3.02 & 4.14 & 4.43 \\
\hline Edge Density (ED) & $\begin{array}{l}\geq 0 \text {, without } \\
\quad \text { limit }\end{array}$ & $\begin{array}{l}\text { Meters per } \\
\text { hectare }\end{array}$ & $\begin{array}{l}\text { Equals the sum of the lengths }(\mathrm{m}) \text { of all edge segments involving the } \\
\text { corresponding patch type, divided by the total landscape area }\left(\mathrm{m}^{2}\right) \text {. }\end{array}$ & 34.43 & 54.46 & 58.37 & 66.27 \\
\hline $\begin{array}{l}\text { Percentage of } \\
\text { Like Adjacencies (PLADJ) }\end{array}$ & $0 \div 100$ & Percent & $\begin{array}{l}\text { Equals the number of like adjacencies involving the focal class, divided } \\
\text { by the total number of cell adjacencies involving the focal class. }\end{array}$ & 98.03 & 97.03 & 96.83 & 96.44 \\
\hline $\begin{array}{l}\text { Interspersion and } \\
\text { Juxtaposition Index (IJI) }\end{array}$ & $0 \div 100$ & Percent & $\begin{array}{l}\text { Equals minus the sum of the length (m) of each unique edge type divided } \\
\text { by the total landscape edge }(\mathrm{m}) \text {, multiplied by the logarithm of the same } \\
\text { quantity, summed over each unique edge type; divided by the logarithm } \\
\text { of the number of patch types times the number of patch types minus } 1 \\
\text { divided by } 2 \text {. }\end{array}$ & 57.93 & 59.31 & 61.53 & 61.23 \\
\hline $\begin{array}{l}\text { Shannon's Diversity Index } \\
\text { (SHDI) }\end{array}$ & $\begin{array}{l}\geq 0 \text {, without } \\
\text { limit }\end{array}$ & None & $\begin{array}{l}\text { Equals minus the sum, across all patch types, of the proportional } \\
\text { abundance of each patch type multiplied by that proportion. }\end{array}$ & 1.12 & 1.29 & 1.34 & 1.40 \\
\hline $\begin{array}{l}\text { Simpson's Diversity Index } \\
\text { (SIDI) }\end{array}$ & $0 \div 1$ & None & $\begin{array}{l}\text { Equals } 1 \text { minus the sum, across all patch types, of the proportional } \\
\text { abundance of each patch type squared. }\end{array}$ & 0.60 & 0.64 & 0.65 & 0.68 \\
\hline
\end{tabular}

Fig. 6. Description of landscape metrics (based on McGarigal et al., 2012) and their values obtained at landscape level for all time intervals under investigation.

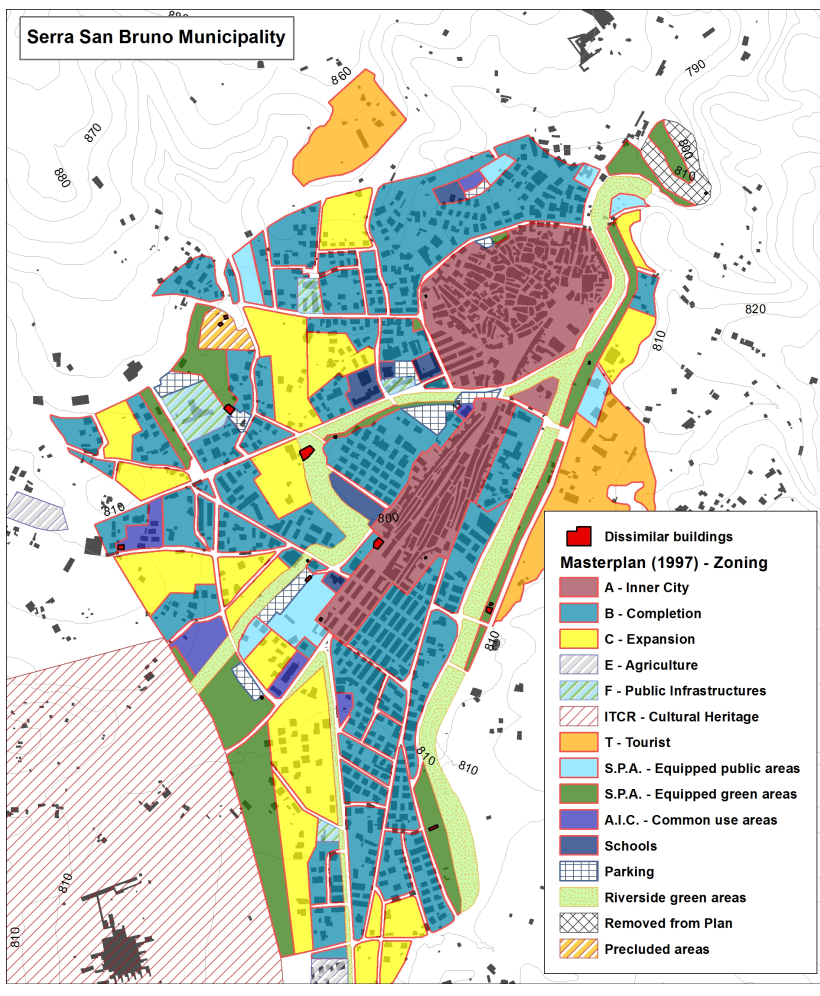

Fig. 7. Analysis of the General Master Plan adopted in 1997, in force until 2007 and currently being updated. like Serra San Bruno. The goal of this analysis was to calculate the effectiveness of zoning: the degree of success of the 1997 GMP was evaluated by taking into account both its indications and built-up expansion in the last $15 \mathrm{yr}$. To this end, a geoprocessing approach was pursued through a GIS overlay of built-up evolution (1994, 2006 and 2011), zoning layer and LULC maps. In compliance with previous studies (e.g. Luck and Wu, 2002; Hahs and McDonnell, 2006), the integration of demographic and physical data, during this phase of the analysis, allowed a better comprehension of the urban-rural gradient evolution.

\subsection{Urban-rural gradient analysis}

In this particular application, urban-rural gradient analysis was performed through three consecutive steps: (1) landscape metrics calculation within FRAGSTAT software using a moving window analysis; (2) Settlement Density Index (SDI) calculation by means of Kernel Density Estimation (KDE); (3) landscape gradients analysis along three significant axes of LULC changes.

\subsubsection{Landscape metrics via moving window analysis}

The window, whose size and shape have to be defined by the user, can be moved over every positively valued cell in the grid, calculating the selected metric within the window, returning that value to the focal (centre) cell and outputting a new continuous surface grid map for the selected metric in which the cell value represents the "local neighbourhood structure" (McGarigal et al., 2012). Several trials were conducted in order to test the impact of the window size on the 


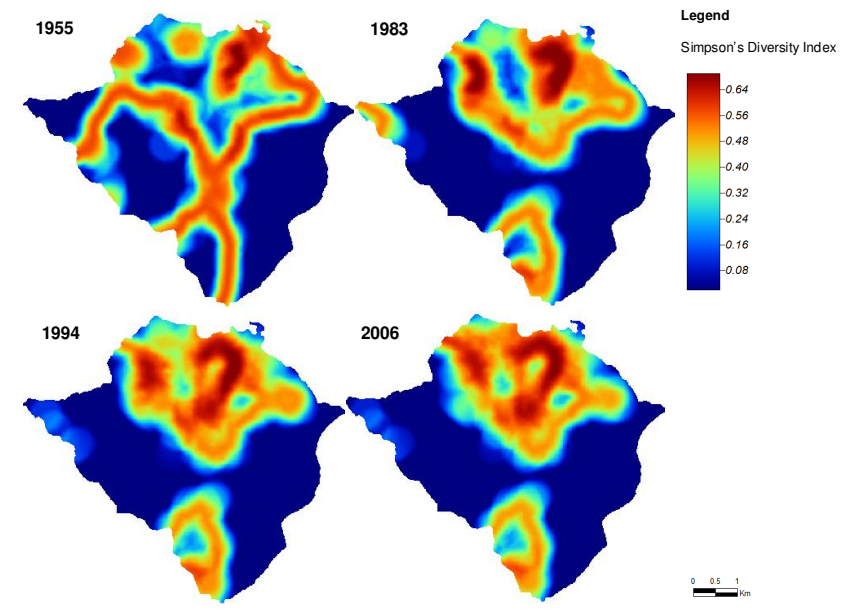

Fig. 8. Simpson's Diversity Index (SIDI) calculated in FRAGSTATS environment using the moving window method.

metrics calculated as well as to improve the smoothing effect on produced maps. According to previous studies, carried out for study areas comparable with the one presented in this paper for both extension and geometric data resolution, results with a $500 \mathrm{~m}$ radius window have proved to be more effective in revealing landscape metrics fluctuations (Kong and Nakagoshi, 2006; Kong et al., 2012). Furthermore, this window size is equal to the one adopted for the SDI implementation described below, so as to produce relevant landscape metrics spatially comparable with the SDI analysis. Considering that FRAGSTATS gives negative values for cells located close to the edge and not fully contained within the window of the input grid (McGarigal et al., 2012), a buffer area (or expansion strip, as it is referred to by McGarigal et al., 2012), equal to the radius of the window size $(500 \mathrm{~m})$, was first defined along the outline of the input LULC raster grid in order to minimise the boundary effect. The maps obtained with this procedure show the spatial distribution of landscape structure based on the results of the selected metrics.

Several landscape metrics were tested across the studyarea in order to better understand landscape change patterns and evolution trends. In this phase of the research, a set of three metrics with moving window analysis were selected, owing to their efficacy in supporting the analysis of urbanrural gradient: Agricultural percentage of landscape (APLAND), Natural percentage of landscape (N-PLAND) and Simpson's Diversity Index (SIDI, Simpson, 1949) (Fig. 8). The first two indices indicate, for every pixel, the proportion of the circular window (centred on the pixel itself) occupied by agricultural land uses (mostly sowable lands) and by natural land covers (grasslands, woodlands, etc.), respectively. Furthermore, in conjunction with SDI, they support the analysis of the main components influencing the urbanrural gradient composition. SIDI has an interpretation that is much more intuitive than Shannon's index (SHDI, Shannon and Weaver, 1949) and less sensitive to the presence of rare types (Nagendra, 2002; McGarigal et al., 2012). Like SHDI, also SIDI has been widely used in several studies for representing landscape diversity changing in space and time. Ranging from 0 (low complexity: only one patch dominates the scene) and 1 (high complexity: all patch types are evenly distributed), Simpson's index defines the probability that two equal-sized and randomly selected sub-units of landscape belong to different class types. This diversity index combines evaluations of richness and evenness. It increases with the increase of the number of class types (richness) and/or when proportional distribution of area among class types becomes more equitable. In turn, since it reflects the patch abundance and heterogeneity in landscapes, the SIDI index can be used to assess landscape diversity. To this end, however, it is necessary to take into account evidence given by Nagendra (2002) on the need for caution when using SHDI and SDI in assessing landscape diversity.

\subsubsection{Settlement density analysis using kernel density estimation}

Analysis of settlement density within GIS environment is generally performed on a discrete basis using areal feature or using a continuous gridding approach. The first method is implemented using a standard overlay technique aimed at the calculation of the intensity of a phenomena (number of buildings) within specific polygonal features (e.g. municipalities, census zones, watersheds, regular squares). The density is calculated for every areal feature through a simple ratio between the number of occurrences and the total area of the corresponding polygon. The shape (often irregular) of the areal feature inevitably weakens the spatial interpretation of settlement densities. Modern gridding techniques allow a continuous density estimation using moving window methods. In simple density analysis, a circular neighbourhood is defined around each raster cell, and the number of events (associated to known locations) that fall within the circle is summed and divided by the area of the neighbourhood (Smith et al., 2007). Generally this kind of approach, although based on a cell-by-cell calculation, produces discontinuities in the output surface (Lloyd, 2007). A very effective alternative is Kernel Density Estimation (KDE) by which density is calculated using a kernel function superimposed over each location. The application of KDE requires the choice of the type of kernel function (e.g. Gaussian, triangular, quartic) and the definition of three key parameters: bandwidth, cell size and intensity. Bandwidth definition is the most problematic step, but also the most useful for exploratory purposes, since a wider radius smooths the spatial variation of the phenomenon and thus shows a more general trend over the study area, while a narrower radius highlights more localized effects, such as "peaks and troughs" in the distribution (Jones et al., 1996). Despite all these approaches, the examination of surfaces resulting from different values of bandwidth remains a 
common method for the definition of this parameter (Gatrell et al., 1996; Lloyd, 2007). In this study, after different tests (bandwidths of 100, 250, 500, 750, $1000 \mathrm{~m}$ ), it was finally decided to adopt a bandwidth of $500 \mathrm{~m}$ in the analysis of buildings density at the working scale. Thus, KDE was performed within SAGA GIS (Böhner et al., 2006) using a quartic function, a cell size of $50 \mathrm{~m}$ and the area occupied by each building as intensity parameter. Considering the method of calculation, the calculated SDI expresses settlement concentration in a given area as the surface occupied by settlements over the territorial surface (Fig. 9). As a consequence, it gives a simplified but reliable representation of the gradient of urbanisation: it assumes maximum values in the central portions of more extensive urban areas and progressively decreases when moving towards less urbanised areas. The same figures show the localisation of the landscape profiles described hereinafter.

\subsubsection{Landscape gradients analysis through linear profiles}

The overall analysis of the urban-rural gradient of the area was performed developing a landscape profiling technique: three different cross-sections (profiles) were located along the main urban development direction with their starting point in the most urbanised area (maximum SDI) (Fig. 9). Using GIS overlay technique, every section was intersected with the four indicator maps of SDI, A-PLAND, N-PLAND and SIDI. The tabular results of the intersection were plotted on different graphs showing the composition and the configuration of the urban-rural gradient along the three landscape cross-sections and its progressive transformations.

\section{Results and discussions}

\subsection{Urban-rural transformations}

During the period examined, all of the stages of land transformations (sensu Forman, 1995; Botequilla Leitão et al., 2006) occurred. Focusing on landscape metrics at landscape and class levels, and considering the results from Patch Density (PD) and Edge Density (ED) indices, the analysis also took into account the Number of Patches (NP) index, which is an index showing the ongoing fragmentation process (Fig. 10). NP increased from 76, in 1955, to 179 , in 2006, while, in the same time interval, PD passed from 1.88 to 4.43. In all LULC classes, both indices grew, except for coniferous (Con-For) and mixed forestry areas (Mix-For), in which the attrition process in land transformation added up to the dissection process, as shown by the increasing ED values for these LULC classes. In the time interval analysed, the increase in the number of patches mainly concerns two LULC types characterised by two different land transformations. On the one hand, particularly referring to discontinuous urban areas, there are two ongoing processes: attrition and perforation (at

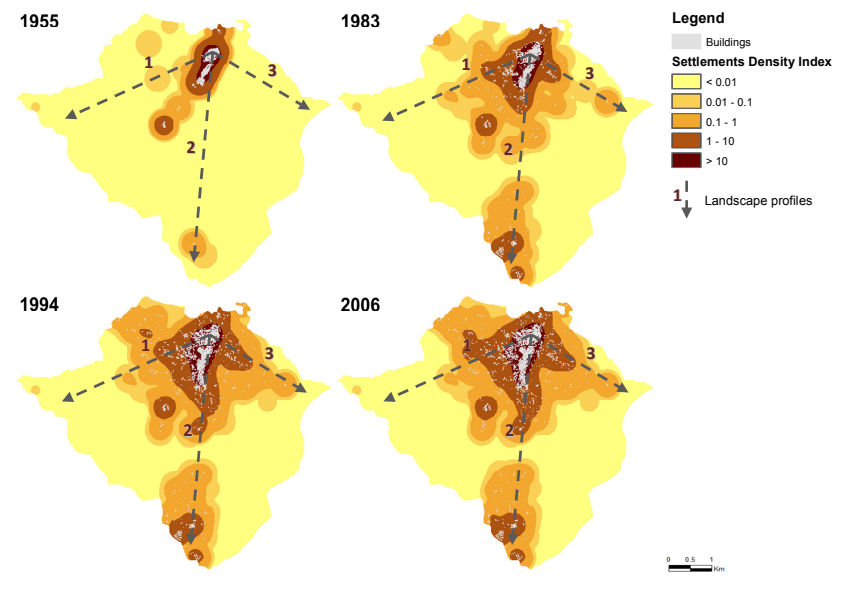

Fig. 9. Maps of the Settlement Density Index (SDI) calculated using Kernel Density Estimation (KDE) for all time intervals investigated. In each map, a localisation of the three defined profiles is shown (Profile 1: direction $251^{\circ}$, length $5 \mathrm{~km}$ - Profile 2: direction $186^{\circ}$, length $6 \mathrm{~km}$ - Profile 3 : direction $118^{\circ}$, length $3.5 \mathrm{~km}$ ).

the expenses of former agricultural areas). On the other hand, in agricultural areas, it is possible to observe a dissection process in addition to perforation. These results are corroborated by the rising trends of PD and ED indices at class levels (Fig. 10).

The urban development of the study area extends along the Ancinale River and two roads, which start from the historical urban nucleus (Fig. 11), go through Serra San Bruno and connect it with the surrounding urban centres. Urbanisation has concerned and is still concerning almost flat and moderate slope areas (slope $\leq 10 \%$ ). The urban fabric LULC class revealed complex and interesting dynamics throughout the period investigated. By 1955, the study area had a quite homogeneous structure, with two definitely prevailing LULC classes: Agric (41.19\%) and Mix-For (47.51\%). The urban fabric was almost completely continuous (Urb-Cont) and coincided with the historical nucleus $(0.89 \%)$. Over time, the urban fabric has been characterised by a dramatic growth, creating an extensive discontinuous built area (Urb-Disc) between the rural and the urban space, which, today, mostly occupies former agricultural lands. Urban areas passed from 4.48 ha, in 1955, to 80.56 ha, in 2006 (Di Fazio et al., 2011). As a result, the areas of greatest expansion of the Urb-Disc class are those next to the historic centre, where they form a continuously evolving outer urban belt. Moreover, the discontinuous urban fabric is still changing: since the 1990s, it has been tending to be incorporated in the Urb-Cont class.

Agricultural areas (Agric) were the most concerned by the changes that occurred in the period under investigation. They passed from 1663.18 ha, in 1955 , to 847.29 ha in 2006 . In the time interval analysed (1955-2006) perforation process was dominant, resulting in a significant landscape change. In 2006, agricultural and forest areas as a whole occupied 

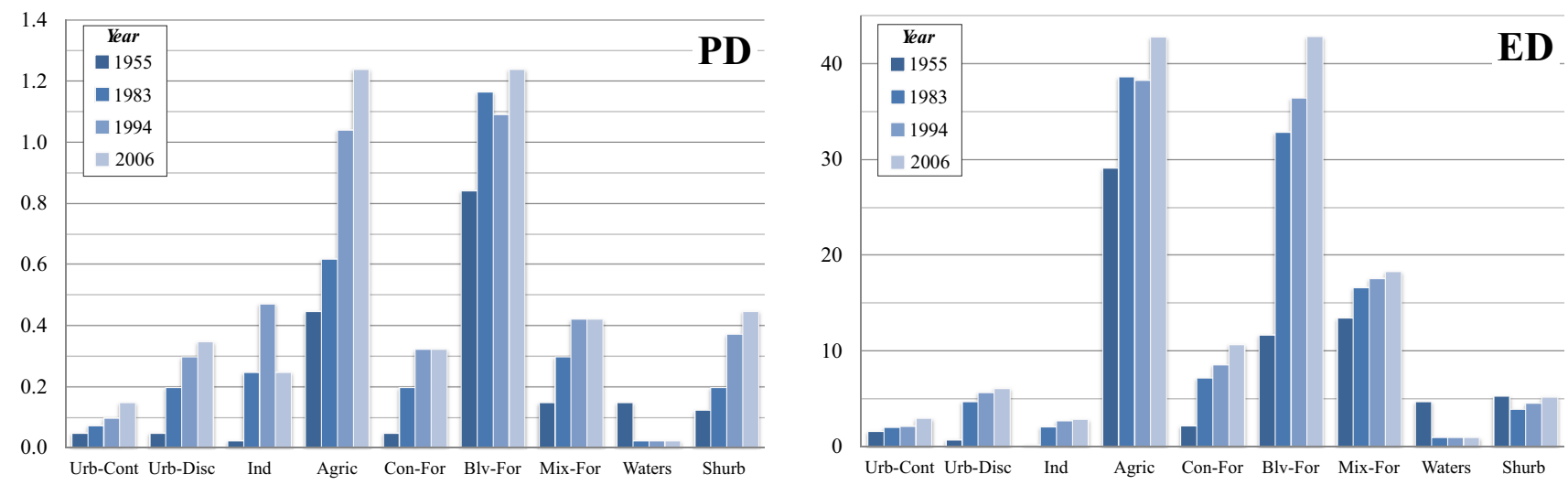

Fig. 10. Patch Density (PD) and Edge Density (ED) landscape metrics calculated at class level for all time intervals defined.

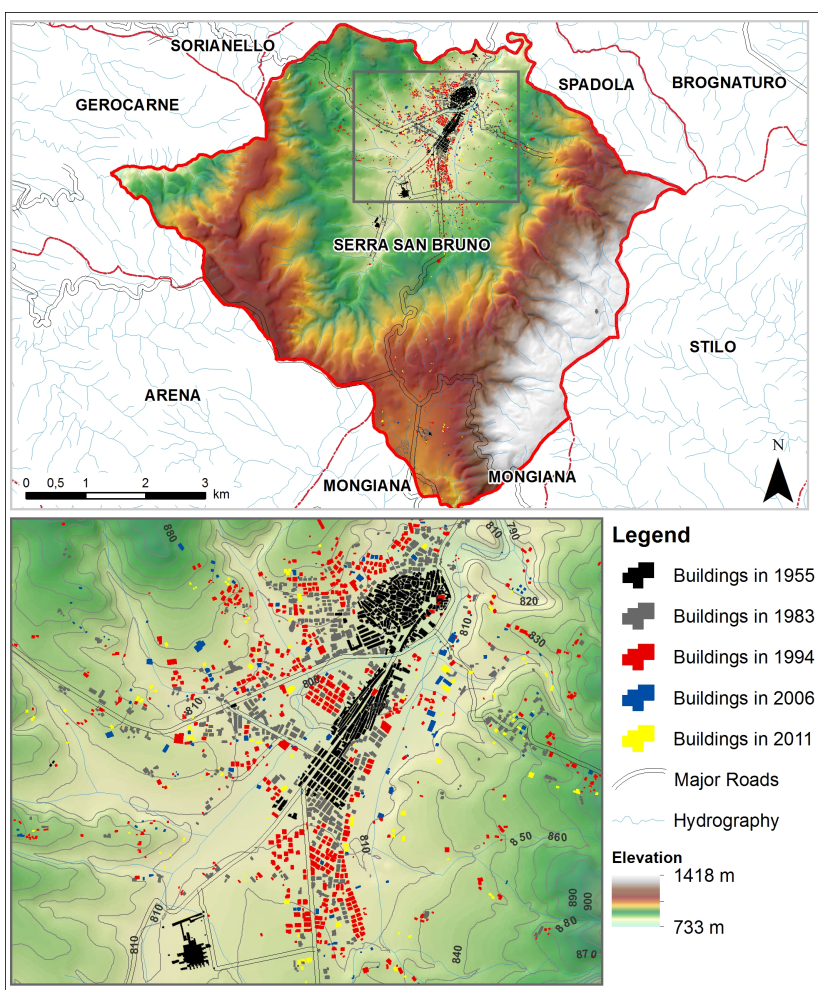

Fig. 11. Overview of the settlement expansion in the study area from 1955 to 2011 superimposed over the Digital Elevation Model (DEM).

$94.32 \%$ of the study area, even though they were differently distributed in comparison with the first period investigated: agricultural areas passed from $41.19 \%$, in 1955 , to $20.98 \%$, in 2006; while forest areas passed from $54.25 \%$, in 1955 , to $73.34 \%$, in 2006 . In agricultural areas, both dissection and fragmentation processes characterised land transformations. In particular, fragmentation is leading today to attrition (gradual loss of remaining fragments), which is indicated as the third and final stage of land transformations
(Botequilla Leitão et al., 2006). In terms of landscape composition (Fig. 4), the area occupied by the Agric class almost halved $(41.19 \%$ in $1955,20.98 \%$ in 2006$)$ because of the intensification of silvicultural activities, of the still rising trend of agricultural abandonment and of the consequent shrub and herbaceous vegetation (Shrub) colonisation of these areas, which, from the point of view of ecological succession, is the initial phase of the process through which forest vegetation regains abandoned agricultural areas. In Calabria, this succession has often been accelerated by reforestation interventions. After the Second World War, they were carried out in large areas and mostly received financial support, first from national and regional public bodies and then from the EU. Forestry areas have always been of crucial importance in the structural dynamics concerning the territory of Serra San Bruno. They are the formations that, in the period under investigation, replaced a considerable part of the area of the Agric class. Today, 705.48 ha $(86.46 \%)$ of the 815.94 ha of the Agric class, which have changed over the fifty years investigated, are forestry areas, 52.72 ha of which are the result of reforestation. In particular, the most significant increase was recorded for the Blv-For class, which passed from 217.44 ha, in 1955, to 725.27 ha, in 2006 .

The dynamics described above are confirmed by the Agricultural Censuses conducted by the Italian National Institute of Statistics (ISTAT), for the years 1970, 1982, 1990, 2000 and 2010. The analysis of data shows that the number of farms has dropped dramatically, passing from 503, in 1970, to 89 , in $2010(-82.3 \%)$. Correspondingly, Utilised Agricultural Area (UAA) has dropped, though less dramatically, from 1027.63 ha, in 1970, to 395.53 ha, in 2010 (-38.49\%), with a consequent doubling of the average area per farm (from 2.04 to 4.44 ha, $+117.6 \%$ ). This was also due to public measures of financial assistance favouring specific interventions of land consolidation, the effects of which have already been highlighted in a previous work referring to the data of the 5th Agricultural Census (year 2000) (Di Fazio et al., 2011). On the basis of the currently available data from 
the 6th Agricultural Census (year 2010), it can be observed that a similar trend (decreasing number of farms, decreasing UAA, decreasing fragmentation of land parcel) concerns the whole Italian territory.

\subsection{Urban growth and general master plan effectiveness}

The trend of the total number of buildings further confirms what has been stated above: 331 in 1955,1011 in 1983, 1829 in 1994, 2057 in 2006 and, finally, 2251 in 2011. The same trend is obtained if the official number of dwellings, provided by ISTAT and shown in Fig. 12, is taken into account. Despite what similar studies in other areas have shown (e.g. Verburg et al., 2001; Bhatta, 2009, Fichera et al., 2012), the growth rate of urban fabric in the concerned study area is not related to population growth rate, which, in general, drives to the expansion of the built-up area. As matter of fact, a comparison of the number of buildings and of the demographic trend in the last decades, which decreased from 8517 inhabitants in 1961 to 6873 in 2011, shows that housing construction in the study area has not met residential needs but has rather answered the purpose of investing in the property market in a period of high monetary inflation (Di Fazio et al., 2011). As shown in Fig. 12, a significant number of houses are unoccupied and many of them are let during summer for the so-called "tourism of return" and, to a lesser extent, for exogenous tourism (Di Fazio et al., 2010). More in detail, the highest rate of housing construction was recorded between 1983 and 1994, when, owing to the temporary lack of effective planning regulations, many buildings were constructed in unsuitable areas. Between 1994 and 2006, a significant downturn in the construction of new buildings was recorded, which did not affect agricultural areas, as it had happened in the past, but rather open spaces in discontinuous urban areas (10.59 ha of the Urb-Disc class turned into Urb-cont).

Then, using the vector-based geoprocessing approach outlined in the previous paragraph, the GIS layers describing the built-up expansion (1994-2011), were juxtaposed on the map of the GMP zoning. At this stage of the analysis, the outputs of this processing were mapped as new GIS layers. It resulted that only very few buildings were built in locations which met GMP zoning definition and standards (Fig. 7). Afterwards, the dynamics within the study area were assessed comparing the amount of land occupied for built-up use with demographic data (e.g. Censuses), in order to analyse how the urban expansion was able to match the population requirements. These results highlight a trend similar to the one described above, corroborating the analysis based on the comparison between number of buildings and population growth. In this case, the comparison of builtup LULC expansion with ISTAT demographic data, during the last twenty-year period (1983-2011), showed a growth rate of the urbanised area higher than the population growth rate, as expected. Just to mention a few data, built-up areas

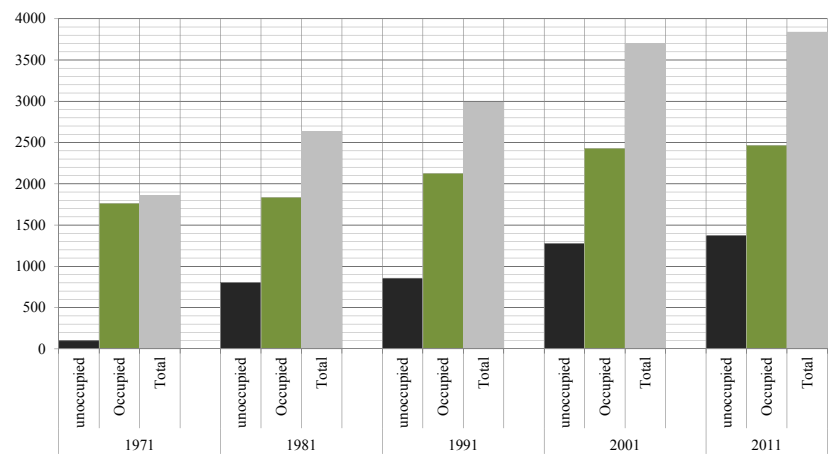

Fig. 12. Number of dwellings per type of occupation in Serra San Bruno municipality in 1971-2011 period (source: ISTAT, Italian National Institute of Statistics).

increased by $26 \%$ between 1983 and 1994 and by $9 \%$ between 1994 and 2011. On the other hand, the population increased only by $6 \%$ between 1981 and 1991 and by $2 \%$ between 1991 and 2011.

\subsection{Urban-rural gradient analysis}

Landscape profile graphs effectively show the main characteristics of the urban-rural gradient using a 2-D space that allow the simultaneous analysis of the four above-mentioned indices (Fig. 13). In all graphs, the $\mathrm{x}$-axis represents the distance from the starting point of the profile; the left $y$-axis shows a percentage scale used for representing SDI and APLAND and N-PLAND curves; the right y-axis shows a probability scale used for representing SIDI curve.

In all the cases, the profile graphs indicate a similar landscape composition and configuration at the very initial part of the three profiles. In this particular context, the small extents of high urbanised areas determine a particular initial composition of the gradient that is not completely urban, since it is also characterised by agricultural and natural areas. Moving from the most urbanised area (the historical town centre) towards rural areas, SDI curves show a decreasing tendency, as expected, while A-PLAND and N-PLAND curves assume a different shape, indicating different types of urban-rural gradients in the three directions under investigation.

The first profile shows a typical urban-agricultural-natural gradient characterised by two clear transitions from an urbandominated landscape to an agriculture-dominated landscape and from the latter to a natural landscape. As expected, landscape diversity is higher within these transitions, which are typical of peri-urban and agroforestry areas, where a more variegated landscape mosaic can be detected. On the contrary, SIDI assumes lower values within the areas dominated by agricultural lands and woodlands. The second profile shows an initial smoother transition between the most urbanised area and the rural one, which is characterised by a growing incidence of natural areas $(0-2.2 \mathrm{~km})$. This part of the profile falls into a mixed landscape marked by high 


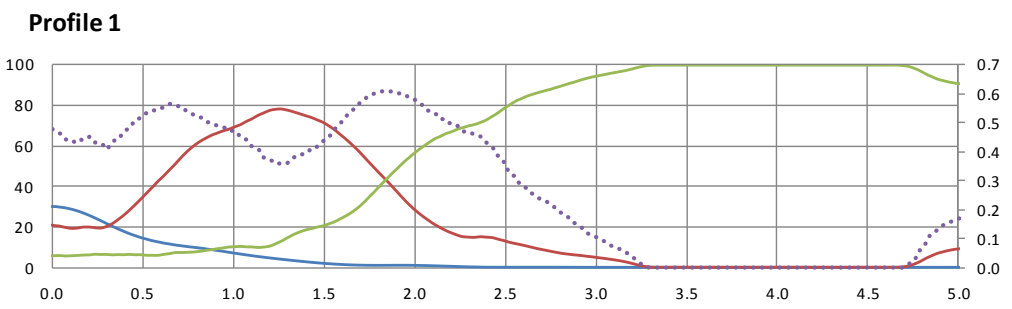

Profile 2
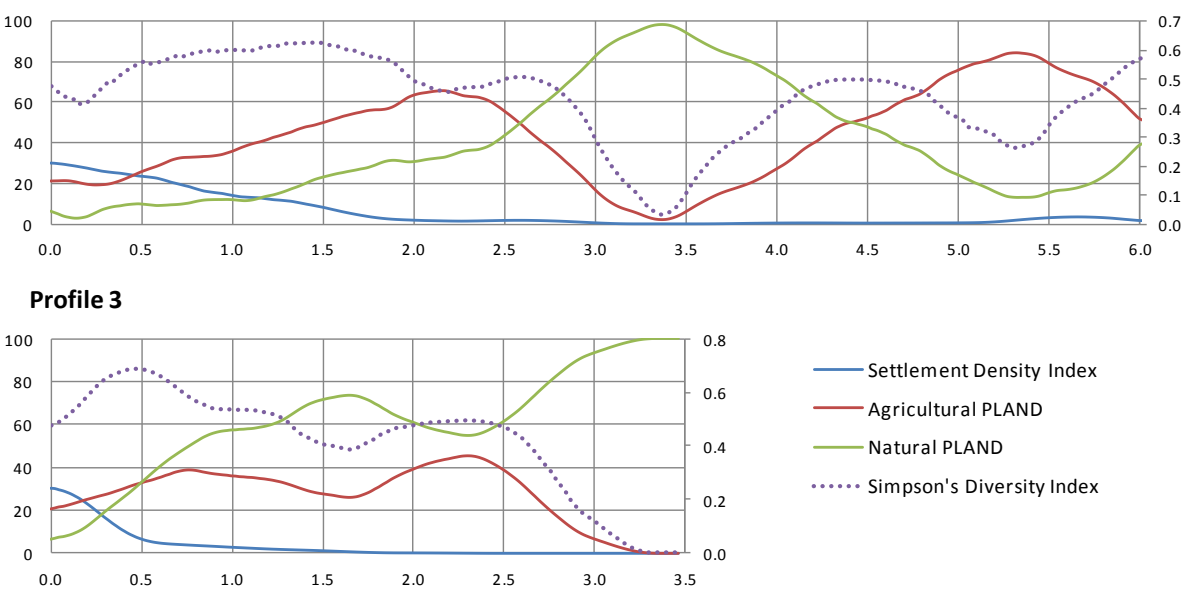

...... Simpson's Diversity Index

Fig. 13. Composition and diversity of the urban-rural gradient measured along the landscape profiles (year 2006). Settlement Density Index, agricultural and natural percentages of landscape (PLAND), and Simpson's Diversity Index (SIDI). The latter is represented using the right graduation on the graphs.

diversity and fragmentation. Along the other part of the profile, the two A-PLAND and N-PLAND curves assume a particular alternating behaviour, indicating the relative incidence of agricultural and natural areas and the position of the agricultural-forestry transitional areas, where SIDI increases as expected. The third profile illustrates another particular urban to rural gradient, with an initial steeper transition from the most urban to a natural-dominated agricultural landscape characterised by high values of diversity. The other section of the profile appears occupied by natural areas.

The transformations of the urban-rural gradient were studied by means of a diachronic analysis of the four indices along the same landscape profiles (Fig. 14) and for all the time intervals defined. All the graphs indicate the variation of each index (positive or negative) occurred along the profile in a specific interval. SDI evolution was analysed on separate graphs taking into account the different magnitude of the temporal variations of this index, while A-PLAND, NPLAND and SIDI variations were plotted, for each profile, using three different graphs corresponding to the three periods under investigation. This approach allowed an efficient spatio-temporal comparative analysis of the transformations of the urban-rural gradient composition and configuration in the study area.

As described above, the most relevant transformations of the landscape gradient took place in the 1955-1983 period.
Thus, all the graphs referring to this period show an evident rise in SDI index, mostly in the first part of the profile, indicating a typical urbanisation process of the outer peri-urban agricultural areas. This process is confirmed by a related decrease in the A-PLAND index observed in the same period. Another important transformation, highlighted by the outer section of the three profiles, is associated to the increase in areas mainly occupied by woodlands inside agriculturaldominated landscape. These modifications, which occurred mainly within urban-agricultural and agricultural-forestry fringes, produced a relevant increase in landscape diversity indicated by the double peaks of SIDI variation curves. The peaks are located exactly at the position of the transitions, which were identified by means of the previous landscape profile analysis. As a consequence, between 1955 and 1983, urban sprawl, on the one hand, and woodlands expansion, on the other, generated deep changes in the urban-rural gradient of the area. The two main processes described above continued, with diminishing magnitude, during the subsequent period 1983-1994, causing further erosion and fragmentation of agricultural landscapes. The variations of diversity along the urban-rural gradient directly reflect those transformations. During the last period, 1994-2006, minor transformations occurred, mainly entailing the urbanisation of small peri-urban areas and the further expansion of woodlands in steeper agricultural areas. As confirmed by SIDI variations, 


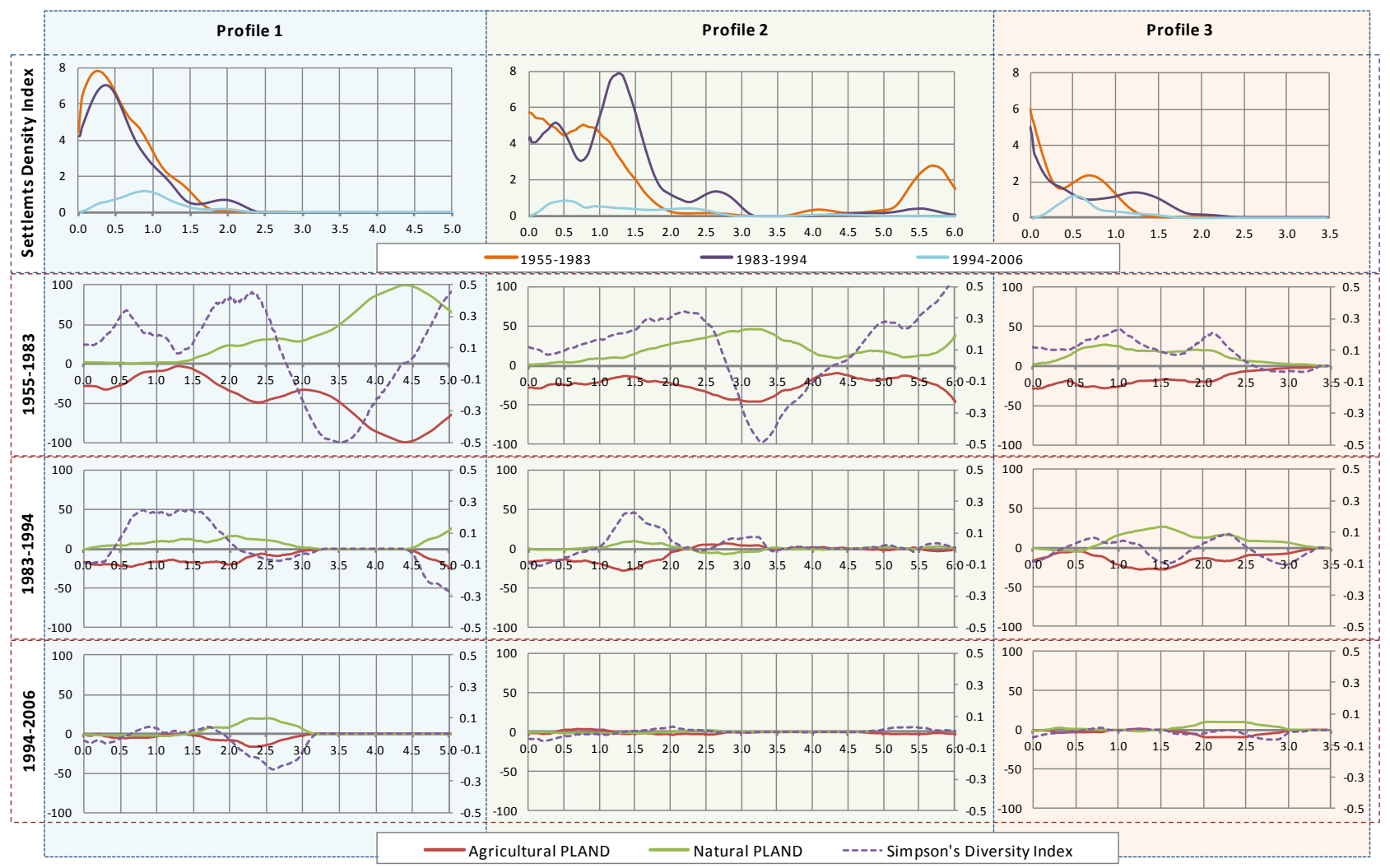

Fig. 14. Transformations of the urban-rural gradient measured along the landscape profiles (kilometres are shown on the $x$-axis). Spatial and temporal variations of Settlement Density Index (SDI), of agricultural and natural percentages of landscape (A-PLAND and N-PLAND) and of Simpson's Diversity Index (SIDI). The latter is represented using the right graduation on the graphs.

these modifications generated only small changes in landscape configuration, also due to the efficacy of the GMP as outlined in Sect. 3.2.

\section{Conclusions}

The research is part of a wider study and is aimed at quantifying and interpreting LULC changes, particularly significant areas of the Mediterranean landscape. Similar to the results of previous research carried out in other Italian Mediterranean landscapes (Fichera et al., 2012), in the last sixty years, the urbanisation process has considerably modified the landscape of Serra San Bruno municipality, with significant land-use conversions. This study has highlighted how understanding the evolution of landscape trends, particularly where the urban/rural dynamic relations play a significant role, is crucial to their sustainable planning. As argued by Botequilla Leitão et al. (2006), developing a basic understanding of landscape changes is fundamental to weigh options and consequences associated with alternative planning options, besides being the best way to deal with them. To that end, in a first phase, the integration of spatial, historical (aerial photographs) and recent (orthophotos) data with socio-economic data, in a geodatabase at a detailed scale, proved to be of great importance to understand the relations between land-use, -cover and -functions (Verburg et al., 2009). The observation and temporal analysis of LULC changes is a procedure that allows to identify ongoing trends and to better understand landscape evolution. Therefore, it is fundamental to implement tools helping to envisage future scenarios (Cerreta and De Toro, 2012; De Montis and Caschili, 2012; Fusco Girard and Torre, 2012). Furthermore, the analysis of LULC changes allows the temporal verification of the positive (e.g. reforestation of agricultural areas, land consolidation, etc.) or negative (lack of landscape planning tools, agricultural abandonment, etc.) effects of past territorial policies. Finally, these analyses can allow the implementation of landscape management tools and sustainable medium- and long-term landscape planning so as to direct future changes towards those which had positive effects and to contrast the past actions which had negative consequences on the landscape. This would have significant impacts not only at a local scale, which was the scope of this research, but also on regional-scale plans and programmes.

This research also offered an example of how GIS techniques and methodologies can be used to support land-use planning and decision making in urban growth management 
(Cerreta and De Toro, 2010; Cerreta et al., 2012; Cerreta and Mele, 2012), by providing helpful tools to spatially analyse and study landscape patterns, spatial variations and their most significant correlations.

Landscape profiling techniques for the analysis of the urban-rural gradient is an innovative and valuable approach for studying gradient characteristics over space and time. The landscape profile graphs allow a very effective diachronic analysis of the urban-rural gradient composition and configuration. The strength of the approach is in its relative simple applicability on every landscape context at the different scales of analysis and in the possibility to effectively compare more graphs referred to different areas under investigation. Certainly, the method needs further improvements, particularly in the selection of relevant metrics for better exploration and analysis of landscape configuration. Moreover, additional research is needed for deeper comprehension of the relations between graph shapes and landscape functions.

Future developments of this research will include the use of WorldView-2 imagery in order to compare automatic land cover classification using object-oriented analysis and automatic settlement extraction comparing different data sources.

Acknowledgements. The authors would like to thank DigitalGlobe ${ }^{\circledR}$ for providing the Worldview-2 imagery under the Erdas Imagine-DigitalGlobe 2012 Geospatial Challenge Contest.

Edited by: H. Asche

\section{References}

Aguilera, F., Valenzuela, L. M., and Botequilha-Leitão, A.: Landscape metrics in the analysis of urban land use patterns: A case study in a Spanish metropolitan area, Landscape Urban Plan., 99, 226-238, doi:10.1016/j.landurbplan.2010.10.004, 2011.

Alberti, M., Solera, G., and Tsetsi, V.: La città sostenibile (Sustainable Cities), Franco Angeli, Milano, Italy, 1994.

Antrop, M.: Changing patterns in the urbanized countryside of Western Europe, Landscape Ecol., 15, 257-270, doi:10.1023/A:1008151109252, 2000.

Antrop, M.: Landscape change and the urbanization process in Europe, Landscape and Urban Plan, 67(1-4), 9-26, doi:10.1016/S0169-2046(03)00026-4, 2004.

Bhatta, B.: Analysis of urban growth pattern using remote sensing and GIS: A case study of Kolkata, India, Int. J. Remote Sens., 30, 4733-4746, doi:10.1080/01431160802651967, 2009.

Blasi, C., Capotorti, G., Smiraglia, D., Guida, D., Zavattero, Z., Mollo, B., Frondoni, R., and Copiz, R.: The Ecoregions of Italy, A thematic contribution to the National Biodiversity Strategy, available at: www.minambiente.it/export/sites/default/archivio/ biblioteca/protezione_natura/ecoregioni_italia_eng.pdf (last access: 20 September 2012), 2010.
Blondel, J.: The "Design" of Mediterranean Landscapes: A Millennial Story of Humans and Ecological Systems during the Historic Period, Hum. Ecol., 34, 713-729, doi:10.1007/s10745-0069030-4, 2006.

Böhner, J., McCloy, K. R., and Strobl, J. (Eds.): SAGA - Analysis and Modelling Applications, Göttinger Geographische Abhandlungen, Germany, Vol. 115, 130 pp, 2006.

Botequilha Leitão, A., Miller, J., Ahern, J., and McGarigal, K.: Measuring landscapes: A planner's handbook, Island Press, Washington DC, USA, 2006.

Botequilha Leitão, A. and Ahern, J.: Applying landscape ecological concepts and metrics in sustainable landscape planning, Landscape Urban Plan., 59, 65-93, doi:10.1016/S01692046(02)00005-1, 2002.

Braimoh, A. K.: Random and systematic land-cover transitions in northern Ghana, Agriculture, Ecosyst. Environ., 113, 254-263, doi:10.1016/j.agee.2005.10.019, 2006.

Cerreta, M. and De Toro, P.: Integrated spatial assessment for a creative decision-making process: a combined methodological approach to strategic environmental assessment, Int. J. Sustain. Dev., 13, 17-30, doi:10.1504/IJSD.2010.035096, 2010.

Cerreta, M. and De Toro, P.: Assessing urban transformations: a SDSS for the master plan of Castel Capuano, Naples, ICCSA 2012, Part II, Lect. Notes Comput. Sc., 7334/2012, 168180, doi:10.1007/978-3-642-31075-1_13, 2012.

Cerreta, M. and Mele, R.: A landscape complex values map: integration among soft values and hard values in a spatial decision support system, ICCSA 2012, Part II, Lect. Notes Comput. Sc., 7334/2012, 653-669, doi:10.1007/978-3-642-31075-1_49, 2012.

Cerreta, M., Panaro, S., and Cannatella, D.: Multidimensional spatial decision-making process: local shared values in action, ICCSA 2012, Part II, Lect. Notes Comput. Sc., 7334/2012, 5470, doi:10.1007/978-3-642-31075-1_5, 2012.

Cihlar, J.: Land cover mapping of large areas from satellites: Status and research priorities, Int. J. Remote Sens., 21, 1093-1114, doi:10.1080/014311600210092, 2000.

Cushman, S. A., McGarigal, K., and Neel, M. C.: Parsimony in landscape metrics: Strength, universality, and consistency, Ecol. Indic., 8, 691-703, doi:10.1016/j.ecolind.2007.12.002, 2008.

Danese, M., Lazzari, M., and Murgante, B.: Kernel density estimation methods for a geostatistical approach in seismic risk analysis: The case study of Potenza hilltop town (southern Italy), ICCSA 2008, Part I, Lect. Notes Comput. Sc., 5072/2008, 415429, doi:10.1007/978-3-540-69839-5_31, 2008.

De Montis, A. and Caschili, S.: Nuraghes and landscape planning: Coupling viewshed with complex network analysis, Landscape Urban Plan., 105, 315-324, doi:10.1016/j.landurbplan.2012.01.005, 2012.

Defries, R. S., Foley, J. A., and Asner, G. P.: Land-use choices: balancing human needs and ecosystem function, Front Ecol. Environ., 2, 249-257, doi:10.1890/15409295(2004)002[0249:LCBHNA]2.0.CO;2, 2004.

Di Fazio, S., Laudari, L., and Modica., G.: Heritage interpretation and landscape character in the forestry district of Serra San Bruno (Calabria, Italy), in: Proceedings of the XVII World Congress International Commission of Agricultural and Biosystems Engineering (CIGR) on Sustainable Biosystems through Engineering, 13-17 June 2010, CSBE101459, Québec City, Canada, 2010. 
Di Fazio, S., Modica, G., and Zoccali, P.: Evolution Trends of Land Use/Land Cover in a Mediterranean Forest Landscape in Italy, ICCSA 2011, Part I, Lect. Notes Comput. Sc., 6782/2011, 284299, doi:10.1007/978-3-642-21928-3_20, 2011.

EEA - European Environment Agency: European forest types, EEA Technical report no. 9, available at: www.eea.europa.eu/ publications/technical_report_2006_9 (last access: 18 September 2012), 2006a.

EEA - European Environment Agency: Urban sprawl in Europe: The ignored challenge, EEA Report no. 10/2006, Publications Office of the European Union, Luxembourg, 2006b.

EEA - European Environment Agency: Landscape fragmentation in Europe, Joint EEA-FOEN report no. 2/2011, EEA Report series, Publications Office of the European Union, Luxembourg, doi:10.2800/78322, 2011.

Farina, A.: Principles and methods in landscape ecology, Chapman \& Hall, London, UK, 1998.

Fichera, C. R., Modica, G., and Pollino, M.: GIS and Remote Sensing to Study Urban-Rural Transformation During a FiftyYear Period, ICCSA 2011, Part I, Lect. Notes Comput. Sc., 6782/2011, 237-252, doi:10.1007/978-3-642-21928-3_17, 2011.

Fichera, C. R., Modica, G., and Pollino, M.: Land Cover classification and change-detection analysis using multi-temporal remote sensed imagery and landscape metrics, Eur. J. Remote Sens., 45, 1-18, doi:10.5721/EuJRS20124501, 2012.

Foley, J. A., Defries, R., Asner, G. P., Barford, C., Bonan, G., Carpenter, S. R., Chapin, F. S., Coe, M. T., Daily, G. C., Gibbs, H. K., Helkowski, J. H., Holloway, T., Howard, E. A., Kucharik, C. J., Monfreda, C., Patz, J. A., Prentice, I. C., Ramankutty, N., and Snyder, P. K.: Global consequences of land use, Science, 309, 570-574, doi:10.1126/science.1111772, 2005.

Forman, R. T. T.: Land Mosaics: The Ecology of Landscapes and Regions, Cambridge University Press, Cambridge, UK, 1995.

Fusco Girard, L. and De Toro, P.: Integrated spatial assessment: a multicriteria approach to sustainable development of cultural and environmental heritage in San Marco dei Cavoti, Italy, Centr. Eur. J. Operat. Res., 15, 281-299, doi:10.1007/s10100-007-0031-1, 2007.

Fusco Girard, L. and Torre, C.: The use of ahp in a multiactor evaluation for urban development programs: a case study, ICCSA 2012, Part II, Lect. Notes Comput. Sc., 7334/2012, 157167, doi:10.1007/978-3-642-31075-1_12, 2012.

Gatrell, A. C., Bailey, T. C., Diggle, P. J., and Rowlingson, B. S.: Spatial Point Pattern Analysis and Its Application in Geographical Epidemiology, T. Inst. British Geogr., 21, 256-274, doi:10.2307/622936, 1996.

Gomarasca, M.: Basics of Geomatics, Springer, the Netherlands, doi:10.1007/978-1-4020-9014-1, 2009.

Gustafson, E. J.: Minireview: Quantifying Landscape Spatial Pattern: What Is the State of the Art?, Ecosystems, 1, 143-156, doi:10.1007/s100219900011, 1998.

Hahs, A. K. and McDonnell, M. J.: Selecting independent measures to quantify Melbourne's urban-rural gradient, Landscape Urban Plan., 78, 435-448, doi:10.1016/j.landurbplan.2005.12.005, 2006.

Hasse, J. E. and Lathrop, R. G.: Land resource impact indicators of urban sprawl, Appl. Geogr., 23, 159-175, doi:10.1016/j.apgeog.2003.08.002, 2003.
Herold, M., Goldstein, N. C., and Clarke, K. C.: The spatiotemporal form of urban growth: measurement, analysis and modeling, Remote Sens. Environ., 86, 286-302, doi:10.1016/S00344257(03)00075-0, 2003.

Herold, M., Couclelis, H., and Clarke, K.: The role of spatial metrics in the analysis and modeling of urban land use change, Comput. Environ. Urban, 29, 369-399, doi:10.1016/j.compenvurbsys.2003.12.001, 2005.

Hidding, M., Needham, B., and Wisserhof, J.: Discourses of town and country, Landscape Urban Plan., 48, 121-130, doi:10.1016/S0169-2046(00)00036-0, 2000.

Hoffhine Wilson, E., Hurd, J. D., Civco, D. L., Prisloe, M. P., and Arnold, C.: Development of a geospatial model to quantify, describe and map urban growth, Remote Sens. Environ., 86, 275285, doi:10.1016/S0034-4257(03)00074-9, 2003.

Jones, M. C., Marron, J. S., and Sheather, S. J.: A Brief Survey of Bandwidth Selection for Density Estimation, J. Am. Stat. Assoc., 91, 401-407, 1996.

Kong, F. and Nakagoshi, N.: Spatial-temporal gradient analysis of urban green spaces in Jinan, China, Landscape Urban Plan., 78, 147-164, doi:10.1016/j.landurbplan.2005.07.006, 2006.

Kong, F., Yin, H., Nakagoshi, N., and James, P.: Simulating urban growth processes incorporating a potential model with spatial metrics, Ecol. Indic., 20, 82-91, doi:10.1016/j.ecolind.2012.02.003, 2012.

$\mathrm{Li}, \mathrm{H}$. and $\mathrm{Wu}, \mathrm{J} . \mathrm{U}$ Use and misuse of landscape indices, Landscape Ecol., 19, 389-399, doi:10.1023/B:LAND.0000030441.15628.d6, 2004.

Lillesand, T., Kiefer, R., and Chipman, J.: Remote sensing and image interpretation, 5th Edn., Wiley, New York, 2003.

Lloyd, C. D.: Local models for spatial analysis. CRC Press Taylor \& Francis Group, Boca Raton, FL, doi:10.1201/EBK1439829196, 2007.

Lu, D., Mausel, P., Brondizio, E., Moran, E., and Brondízio, E.: Change detection techniques, Int. J. Remote Sens., 25, 2365 2401, doi:10.1080/0143116031000139863, 2004.

Luck, M. and Wu, J.: A gradient analysis of urban landscape pattern: a case study from the Phoenix metropolitan region, Arizona, USA, Landscape Ecol., 17, 327-339, doi:10.1023/A:1020512723753, 2002.

McDonnell, M. J. and Hahs, A. K.: The use of gradient analysis studies in advancing our understanding of the ecology of urbanizing landscapes: current status and future directions, Landscape Ecol., 23, 1143-1155, doi:10.1007/s10980-008-9253-4, 2008.

McDonnell, M. J. and Pickett, S. T. A.: Ecosystem Structure and Function along Urban-Rural Gradients: An Unexploited Opportunity for Ecology, Ecology, 71, 1232, doi:10.2307/1938259, 1990.

McGarigal, K. and Cushman, S. A.: The gradient concept of landscape structure, in: Issues and Perspectives in Landscape Ecology, edited by: Wiens, J. and Moss, M., Cambridge University Press, Cambridge, UK, 112-119, 2005.

McGarigal, K., Cushman, S. A., and Ene, E.: FRAGSTATS v4: Spatial Pattern Analysis Program for Categorical and Continuous Maps, Computer software program produced by the authors at the University of Massachusetts, Amherst, available at: www. umass.edu/landeco/research/fragstats/fragstats.html, last access: 31 July 2012. 
Mercurio, R.: Restauro della foresta mediterranea (Restoration of the Mediterranean Forest), Clueb, Bologna, Italy, 368 pp., 2010.

Murgante, B. and Danese, M.: Urban versus Rural: the decrease of agricultural areas and the development of urban zones analyzed with spatial statistics, Int. J. Agr. Environ. Inform. Syst., 2, 1628, doi:10.4018/jaeis.2011070102, 2011.

Myers, N., Mittermeier, R., and Mittermeier, C.: Biodiversity hotspots for conservation priorities, Nature, 403, 853-858, doi:10.1038/35002501, 2000.

Nagendra, H.: Opposite trends in response for the Shannon and Simpson indices of landscape diversity, Appl. Geogr., 22, 175186, doi:10.1016/S0143-6228(02)00002-4, 2002.

Neri, M., Menconi, M. E., Vizzari, M., and Mennella, V.: A proposal of a new methodology for best location of environmentally sustainable roads infrastructures. Validation along the Fabriano-Muccia road, Informes de la Construcción, 517, 101112, doi:10.3989/ic.09.043, 2010.

Ode, A., Tveit, M. S., and Fry, G.: Advantages of using different data sources in assessment of landscape change and its effect on visual scale, Ecol. Indic., 10, 24-31, doi:10.1016/j.ecolind.2009.02.013, 2010.

Peng, J., Wang, Y., Zhang, Y., Wu, J., Li, W., and Li, Y.: Evaluating the effectiveness of landscape metrics in quantifying spatial patterns, Ecol. Indic., 10, 217-223, doi:10.1016/j.ecolind.2009.04.017, 2010.

Perchinunno, P., Rotondo, F., and Torre, C.: The Evidence of Links between Landscape and Economy in a Rural Park, Int. J. Agr. Environ. Inform. Syst., 3, 1-14, doi:10.4018/jaeis.2012070105, 2012.

Perella, G., Galli, A., and Marcheggiani, E.: The Potential of Ecomuseums in Strategies for Local Sustainable Development in Rural Areas, Landscape Res., 35, 431-447, doi:10.1080/01426397.2010.486854, 2010.

Poelmans, L. and Van Rompaey, A.: Detecting and modelling spatial patterns of urban sprawl in highly fragmented areas: A case study in the Flanders-Brussels region, Landscape Urban Plan., 93, 10-19, doi:10.1016/j.landurbplan.2009.05.018, 2009.

Quezel, P. and Medail, F.: Ecologie et biogéographie des forets du bassin méditerranéen, Elsevier, Paris, 576 pp., 2003.

Selicato, M., Torre, C., and Trofa, G. L.: Prospect of integrate monitoring: a multidimensional approach, ICCSA 2012, Part II, Lect. Notes Comput. Sc., 7334/2015, 144-156, doi:10.1007/9783-642-31075-1_11, 2012.

Seto, K. C. and Fragkias, M.: Quantifying Spatiotemporal Patterns of Urban Land-use Change in Four Cities of China with Time Series Landscape Metrics, Landscape Ecol., 20, 871-888, doi:10.1007/s10980-005-5238-8, 2005.

Shannon, C. E. and Weaver, W.: The mathematical theory of communication, University of Illinois Press, Urbana, IL, 1949.

Silverman, B. W., Jones, M. C., Fix, E., and Hodges, J. L.: An Important Contribution to Nonparametric Discriminant Analysis and Density Estimation: Commentary on Fix and Hodges (1951), Int. Stat. Rev., 57, 233-247, doi:10.2307/1403796, 1989.
Simpson, E. H.: Measurement of diversity, Nature, 163, p. 688, doi:10.1038/163688a0, 1949.

Smith, M. J., Goodchild, M. F., and Longley, P. A.: Geospatial Analysis: A Comprehensive Guide to Principles, Techniques and Software Tools, Troubador Publishing, Leicester, UK, 2007.

Sudhira, H. S., Ramachandra, T. V., and Jagadish, K. S.: Urban sprawl: metrics, dynamics and modelling using GIS, Int. J. Appl. Earth Obs., 5, 29-39, doi:10.1016/j.jag.2003.08.002, 2004.

Torrens, P. A. and Alberti, M.: Measuring sprawl, CASA Centre for Advanced Spatial Analysis, Working paper 27, available at: www.bartlett.ucl.ac.uk/casa/pdf/paper27.pdf, last access: 24 July 2012, University College London, London, 2000.

Turner, M. G. and Ruscher, C. L.: Changes in landscape patterns in Georgia, USA, Landscape Ecol., 1, 241-251, doi:10.1007/BF00157696, 1988.

Updike, T. and Comp, C.: Radiometric use of WorldView-2 imagery, Technical Note, DigitalGlobe Inc., 2010.

Uuemaa, E., Antrop, M., Roosaare, J., Marja, R., and Mander, Ü.: Landscape Metrics and Indices: An Overview of Their Use in Landscape Research, Living Rev. Landscape Res., 3, 128, available at: www.livingreviews.org/lrlr-2009-1 (last access: 25 July 2012), 2009.

Verburg, P. H., Koning, G. H. J., Kok, K., Veldkamp, A., and Priess, J.: The CLUE modelling framework: an integrated model for the analysis of land use change, in: Land Use and Cover Change, edited by: Singh, R. B., Jefferson, F., and Himiyama, Y., Science Publishers, Enfield, NH, 11-25, 2001.

Verburg, P. H., van de Steeg, J., Veldkamp, A., and Willemen, L.: From land cover change to land function dynamics: a major challenge to improve land characterization, J. Environ. Manage., 90, 1327-1335, doi:10.1016/j.jenvman.2008.08.005, 2009.

Vitousek, P. M.: Human Domination of Earth's Ecosystems, Science, 277, 494-499, doi:10.1126/science.277.5325.494, 1997.

Vizzari, M.: Spatio-temporal analysis using urban-rural gradient modelling and landscape metrics, ICCSA 2011, Part I, Lect Notes Comput Sc, 6782/2011, 103-118, doi:10.1007/978-3-64221928-3_8, 2011a.

Vizzari, M.: Spatial modelling of potential landscape quality, Appl. Geogr., 31, 108-118, doi:10.1016/j.apgeog.2010.03.001, 2011b.

Weng, Y. C.: Spatiotemporal changes of landscape pattern in response to urbanization, Landscape Urban Plan., 81, 341-353, doi:10.1016/j.landurbplan.2007.01.009, 2007.

Wu, J. and Hobbs, R.: Key issues and research priorities in landscape ecology: an idiosyncratic synthesis, Landscape Ecol., 17, 355-365, doi:10.1023/A:1020561630963, 2002.

Yang, Y., Zhou, Q., Gong, J., and Wang, Y.: Gradient analysis of landscape spatial and temporal pattern changes in Beijing metropolitan area, Sci. China Technol. Sci., 53, 91-98, doi:10.1007/s11431-010-3206-2, 2010.

Zhou, W., Schwarz, K., and Cadenasso, M. L.: Mapping urban landscape heterogeneity: agreement between visual interpretation and digital classification approaches, Landscape Ecol., 25, 53-67, doi:10.1007/s10980-009-9427-8, 2009. 